\title{
Soil-nutrient availability affected by different biomass-ash applications
}

\author{
M. Quirantes, F. Calvo, E. Romero, R. Nogales* \\ Department of Environmental Protection, Estación Experimental del Zaidin, Spanish Council for Scientific \\ Research, (EEZ-CSIC), c/ Profesor Albareda 1, 18008 Granada, Spain \\ *Corresponding author: rogelio.nogales@eez.csic.es
}

\begin{abstract}
This study, through an incubation experiment, evaluates the effect that different biomass ashes exert on the extractability of nutrients and some chemical parameters and dehydrogenase activity of a slightly acid soil. Three types of as were selected: two new ashes generated by the dry combustion of olive cake or by gasification of greenhouse vegetable wastes, and a third produced by wood combustion. The ash significantly increased the $\mathrm{pH}$, electrical conductivity, and dehydrogenase activity of the soil. Dry olive-cake ash was the most effective in raising the levels of soil AB-DTPA extractable $\mathrm{P}, \mathrm{K}$, and $\mathrm{Cu}$. By contrast, wood ash caused the greatest increases in soil AB-DTPA-extractable $\mathrm{Zn}$. The three as he showed little effectiveness for increasing soil ABDTPA extractable Fe and Mn. Ash from dry olive cake could be used as a low-cost potassium fertilizer.
\end{abstract}

Keywords: Wood ash, dry olive cake ash, greenhouse vegetable wastes ash, soil incubation, dehydrogenase activity, AB-DTPA extractable nutrients

\section{Introduction}

Biomass is the most important global renewable energy resource, used in developed as well as developing countries. Biomass ashes are the final products accumulating from the thermal combustion and gasification of biomass for heat and electricity production.

Many studies have shown that wood ash applied to agricultural, forestry, and grass lands is practical for enriching soils and boosting yields (Demeyer et al., 2001; Knapp and Insam, 2011). Andalusia is the leader in Spain in generating power using biomass, having 18 power plants with a total capacity of 205 MW. Over $75 \%$ of the biomass comes from the wastes generated by the olive-oil industry (olive cake, among others), followed by the wood debris and plant wastes produced by the greenhouses. Today, scant information is available concerning the characteristics and potential agricultural use of new types of biomass ash.

ABDTPA extraction is a universal soil test used for assessing available macro- and micronutrients as well as some heavy metals in soils (Soltanpour and 
Schwab 1977). It has been used to diagnose soilnutrient deficiencies, to assess soils polluted with heavy metals, and to predict the crop-yield responses to nutrient addition (Molina et al., 2012; Hosseinpur and Motaghian, 2015)

In this study, the effects of different types of biomass ash on the soil nutrients availability were compared. Therefore, three types were assayed; the two new types of ash indicated above and a third produced by wood combustion. In addition, the changes of some soil chemical parameters and dehydrogenase activity were also determined.

\section{Materials and Methods}

A slightly acid, sandy loam (Chromic cambisol) soil (S) with $\mathrm{C} / \mathrm{N}$ of 7 was used in this study. Three biomass ash were used: wood ash (W) produced by at $350^{\circ} \mathrm{C}$, dry olive-cake ash (O) by burning at $450^{\circ} \mathrm{C}$, and greenhouse vegetable waste ash $(\mathrm{G})$ by gasification at $270{ }^{\circ} \mathrm{C}$. The total nutrient concentrations in the $\mathrm{W}$, $\mathrm{O}$, and $\mathrm{G}$ ash were, respectively: P: $1,4.2$, and $2.7 \mathrm{~g}$ $\mathrm{kg}^{-1} ; \mathrm{K}: 6.4,58$ and $31 \mathrm{~g} \mathrm{~kg}^{-1}$; Fe: $16,6.3$, and $9.7 \mathrm{~g}$ $\mathrm{kg}^{-1}$; Mn: 386, 172, and $379 \mathrm{mg} \mathrm{kg}^{-1}$; $\mathrm{Cu}: 247,181$, and $88 \mathrm{mg} \mathrm{kg}^{-1}$ and $\mathrm{Zn}: 2054,274$, and $169 \mathrm{mg} \mathrm{kg}^{-1}$. Other properties of the soil and ash are given in Table 1 .

Table 1. $\mathrm{pH}$, electrical conductivity (EC), total organic carbon (TOC), dehydrogenase activity (DHA) and ABDTPA nutrients in the soil, biomass ash and in the treatments after 32 weeks of incubation

\begin{tabular}{|c|c|c|c|c|c|c|c|c|c|c|}
\hline & $\mathrm{pH}$ & $\begin{array}{c}\text { EC } \\
\mathrm{dS} \mathrm{m}{ }^{-1}\end{array}$ & $\begin{array}{l}\text { TOC } \\
\mathrm{g} \mathrm{kg}^{-1}\end{array}$ & $\begin{array}{c}\text { DHA } \\
\mu \mathrm{g} \text { INTF } \mathrm{g}^{-1} \mathrm{~h}^{-1}\end{array}$ & $\begin{array}{c}\text { AB-DTPA P } \\
\mathrm{mg} \mathrm{kg}^{-1}\end{array}$ & $\begin{array}{c}\text { AB-DTPA K } \\
\mathrm{mg} \mathrm{kg}^{-1}\end{array}$ & $\begin{array}{c}\text { AB-DTPA Fe } \\
\mathrm{mg} \mathrm{kg}^{-1}\end{array}$ & $\begin{array}{c}\text { AB-DTPA Mn } \\
\mathrm{mg} \mathrm{kg}^{-1}\end{array}$ & $\begin{array}{c}\text { AB-DTPA Cu } \\
\mathrm{mg} \mathrm{kg}^{-1}\end{array}$ & $\begin{array}{c}\text { AB-DTPA Zn } \\
\mathrm{mg} \mathrm{kg}^{-1}\end{array}$ \\
\hline S & $6.4 \pm 0.05$ & $0.12 \pm 0.01$ & $7.6 \pm 0.4$ & $0.90 \pm 0.02$ & $0.02 \pm 0.0$ & $43 \pm 1$ & $44 \pm 1$ & $31 \pm 1$ & $1.1 \pm 0.2$ & $0.83 \pm 0.05$ \\
\hline W & $12.8 \pm 0.3$ & $6 \pm 0.4$ & $9.4 \pm 0.5$ & nd & $3.8 \pm 0.2$ & $90 \pm 9$ & $46 \pm 3$ & $386 \pm 20$ & $31 \pm 1$ & $299 \pm 22$ \\
\hline $\mathrm{O}$ & $10.7 \pm 0.4$ & $132 \pm 5$ & $9.4 \pm 0.5$ & nd & $106 \pm 3$ & $19000 \pm 660$ & $0.92 \pm 0.12$ & $172 \pm 5$ & $73 \pm 2$ & $69 \pm 1$ \\
\hline G & $9.9 \pm 0.3$ & $42.1 \pm 2$ & $93 \pm 2$ & nd & $22 \pm 2$ & $9000 \pm 195$ & $76 \pm 5$ & $379 \pm 14$ & $18 \pm 1$ & $66 \pm 3$ \\
\hline & \multicolumn{10}{|c|}{ After 32 weeks of incubation* } \\
\hline C & $5.79 \pm 0.11 \mathrm{a}$ & $0.40 \pm 0.03 \mathrm{a}$ & $6.9 \pm 0.5 \mathrm{c}$ & $0.60 \pm 0.1 \mathrm{a}$ & $0.01 \pm 0.0 \mathrm{a}$ & $48 \pm 1 \mathrm{a}$ & $63 \pm 3 \mathrm{e}$ & $11.3 \pm 1 \mathrm{a}$ & $1.0 \pm 0.04 \mathrm{a}$ & $0.73 \pm 0.06 \mathrm{a}$ \\
\hline+ W5 & $7.4 \pm 0.1 \mathrm{~b}$ & $0.49 \pm 0.06 \mathrm{a}$ & $5.70 \pm 0.5 \mathrm{ac}$ & $1.36 \pm 0.1 \mathrm{~b}$ & $0.07 \pm 0.01 \mathrm{ab}$ & $44 \pm 1 \mathrm{a}$ & $54 \pm 4 d$ & $12 \pm 2$ & $1.35 \pm 0.39 \mathrm{ab}$ & $2.47 \pm 0.3 \mathrm{lc}$ \\
\hline$+\mathrm{W} 25$ & $8.05 \pm 0.22 \mathrm{~cd}$ & $0.76 \pm 0.1 \mathrm{a}$ & $5.0 \pm 0.5 \mathrm{ab}$ & $1.25 \pm 0.1 \mathrm{~b}$ & $0.19 \pm 0.0 \mathrm{lbc}$ & $48 \pm 1 \mathrm{a}$ & $46 \pm 2 c$ & $12.5 \pm 0.5 \mathrm{a}$ & $2.13 \pm 0.27 \mathrm{c}$ & $9.64 \pm 0.39 \mathrm{e}$ \\
\hline$+\mathrm{O} 5$ & $8.34 \pm 0.05 \mathrm{~d}$ & $1.84 \pm 0.06 \mathrm{~b}$ & $5.1 \pm 0.4 \mathrm{ab}$ & $1.54 \pm 0.1 \mathrm{~b}$ & $1.08 \pm 0.1 \mathrm{e}$ & $1265 \pm 82 \mathrm{c}$ & $42 \pm 1 b c$ & $13 \pm 1.1 \mathrm{ab}$ & $1.75 \pm 0.08 \mathrm{bc}$ & $1.75 \pm 0.11 \mathrm{~b}$ \\
\hline$+\mathrm{O} 25$ & $10.4 \pm 0.1 \mathrm{e}$ & $12.8 \pm 0.7 \mathrm{~d}$ & $4.4 \pm 0.6 \mathrm{a}$ & $1.63 \pm 0.3 b$ & $1.97 \pm 0.07 \mathrm{f}$ & $7100 \pm 406 c$ & $35 \pm 5 \mathrm{ab}$ & $14.7 \pm 0.7 \mathrm{~b}$ & $3.89 \pm 0.24 \mathrm{~d}$ & $4.15 \pm 0.05 \mathrm{~d}$ \\
\hline$+\mathrm{G} 5$ & $7.4 \pm 0.1$ & $1.10 \pm 0.02 \mathrm{a}$ & $6.0 \pm 0.7 \mathrm{bc}$ & $1.42 \pm 0.1 b$ & $0.24 \pm 0.03 \mathrm{c}$ & $69 \pm 1 \mathrm{ab}$ & $39 \pm 1 b c$ & $11.6 \pm 0.4 \mathrm{a}$ & $1.10 \pm 0.03 \mathrm{a}$ & $1.12 \pm 0.16 \mathrm{a}$ \\
\hline$+\mathrm{G} 25$ & $7.69 \pm 0.06 \mathrm{bc}$ & $3.72 \pm 0.16 \mathrm{c}$ & $5.6 \pm 0.5 \mathrm{ac}$ & $1.5 \pm 0.3 b$ & $0.77 \pm 0.05 \mathrm{~d}$ & $487 \pm 14 b$ & $28 \pm 1 \mathrm{a}$ & $12.2 \pm 0.9 \mathrm{a}$ & $1.70 \pm 005 \mathrm{lbc}$ & $2.22 \pm 0.02 \mathrm{c}$ \\
\hline
\end{tabular}

S: Soil; W: wood ash; O: dry olive-cake ash; G: greenhouse vegetable waste ash; C: unamended soil; +W5: soil amended with 5 $\mathrm{Mg} \mathrm{ha}^{-1}$ of wood ash; +W25: soil amended with $25 \mathrm{Mg} \mathrm{ha}^{-1}$ of wood ash; +O5: soil amended with $5 \mathrm{Mg} \mathrm{ha}^{-1}$ of dry olive-cake ash; +W25: soil amended with $25 \mathrm{Mg} \mathrm{ha}^{-1}$ of dry olive-cake ash; +G5: soil amended with $5 \mathrm{Mg} \mathrm{ha}^{-1}$ of greenhouse vegetable waste; +W25: soil amended with $25 \mathrm{Mg} \mathrm{ha}^{-1}$ of greenhouse vegetable waste ash.

*After 32 weeks of incubation, means \pm SD in the same column followed by same letters are not significantly different from each other $(p<0.05)$. 
The incubation experiment was performed in a dark growth chamber $\left(25 \pm 1^{\circ} \mathrm{C}\right)$ for 32 weeks. Three pots were prepared, containing $100 \mathrm{~g}$ of the soil $(<2 \mathrm{~mm})$ either unamended (Control, C) or amended with 5 $\mathrm{Mg} \mathrm{ha}^{-1}(1 / 150 \mathrm{ash} / \mathrm{soil}, \mathrm{v} / \mathrm{v})$ or $25 \mathrm{Mg} \mathrm{ha}^{-1}(1 / 30 \mathrm{ash} /$ soil, v/v) of each biomass ash $(<2 \mathrm{~mm})$. During the incubation period, the soil moisture in each pot was maintained at $80 \%$ water-holding capacity. After the incubation period, soil samples of pots were divided into two parts: one part was air dried for chemical analysis while the other part was stored in a plastic vial at $-20{ }^{\circ} \mathrm{C}$ until dehydrogenase activity was determined.

Soil texture, $\mathrm{pH}$, electrical conductivity, total organic carbon (TOC), nitrogen, and total concentrations of nutrients in ashes after the digestion with concentrated aqua regia were determined following validated official methods (MAPA, 1986). Available P, K, Fe, $\mathrm{Mn}, \mathrm{Cu}$, and $\mathrm{Zn}$ were extracted from soil or ashes with $1 \mathrm{M} \mathrm{NH}_{4} \mathrm{HCO}_{3}-0.005 \mathrm{M}$ diethylenetriaminepenta acetic acid (AB-DTPA), pH 7.6 on a $1: 2 \mathrm{w} / \mathrm{v}$ (Soltanpour and Schwab, 1977). In the extracts, P was measured using the ammonium vanadomolyb date method; $\mathrm{K}$ by flame-photometry; and $\mathrm{Fe}, \mathrm{Mn}, \mathrm{Cu}$, and $\mathrm{Zn}$ with atomic-absorption spectrophotometer (GBC 932 plus). Finally, dehydrogenase activity DHA was determined according to García et al., 1997).

\section{Results and Discussion}

Application of the biomass ash significantly raised the $\mathrm{pH}$ and electrical conductivity of the soil (Table 1). The liming effect of the ashes can be attributed to the high alkalinity and to $\mathrm{Ca}, \mathrm{Mg}$, and $\mathrm{K}$ carbonates in the ashes as well as to its fine structure (Sirikare et al., 2015 and authors therein). The increases in soil electrical conductivity depended on the amount of ash applied and on the soluble-salt content in each ash, this being highest in the dry olive-cake ash. The total organic carbon content (TOC) of the soil diminished after the application of different biomass ashes. Dehydrogenase, an intracellular enzyme involved in oxidative phosphorylation, the activity of which is used to assess overall microbial activity in soils, increased significantly after the addition of ashes (Table 1). This fact would be related to the rising $\mathrm{pH}$, which would stimulate soil microbial biomass and activity, and therefore the biological soil fertility in acid soils (Bougnon et al., 2011).

Dry olive-cake ash was the most effective in raising the levels of soil AB-DTPA extractable P, K, and $\mathrm{Cu}$ (Table 1). By contrast, wood ash (W) caused the greatest increases in soil AB-DTPA-extractable $\mathrm{Zn}$. The effectiveness of ashes assayed in increasing soil available $\mathrm{P}, \mathrm{K}, \mathrm{Cu}$, and $\mathrm{Zn}$ depended on the dose applied and the total nutrient concentration, and was closely correlated $(p<0.001)$ with the ABDTPA levels of these nutrients extracted from the ash. The capacity of the ashes assayed for increasing the soil availability of these nutrients was very low for $\mathrm{P}(<3 \%)$, moderate for $\mathrm{Cu}$ and $\mathrm{Zn}(15-40 \%)$, and higher for $\mathrm{K}$, especially when dry olive ash was applied ( $>50 \%)$. The phosphorus content in the ash would be occluded mostly with aluminium silicate or weakly soluble as aluminium phosphate, whereby only a small fraction increases the available soil $\mathrm{P}$ after ash addition (Omil et al., 2011). Although a fraction of $\mathrm{K}, \mathrm{Cu}$, and $\mathrm{Zn}$ in the ash can form insoluble complexes, other major fractions appear in the form of oxides, hydroxides, carbonates, and bicarbonates with different degrees of dissolution (Demeyer et al., 2001 and authors therein), appreciably increasing the available soil $\mathrm{K}, \mathrm{Cu}$, and $\mathrm{Zn}$ (Huotori et al., 2006). The high concentrations of $\mathrm{Zn}$ and $\mathrm{Cu}$ recorded in the wood ash (2064 and $247 \mathrm{mg} \mathrm{kg}^{-1}$, respectively), came possibly from burning wood panels that still had paints and metal elements (Krook et al., 2006). 
The types of ash assayed proved less effective in raising the levels of soil AB-DTPA extractable Fe and $\mathrm{Mn}$ (Table 1). This was presumably due, first, to the soil's very high contents in Fe and Mn extracted with AB-DTPA (Soltanpour, 1985), which may mask the effect of ash applied. In addition, despite that the ashes had high levels of total $\mathrm{Fe}$ and $\mathrm{Mn}$, both micronutrients must form part of the crystal structure of these materials, reducing their availability after application to the soil ( $<1 \%$ for $\mathrm{Fe},<5 \%$ for $\mathrm{Mn})$. Finally, the rise in soil $\mathrm{pH}$ due to the ash applied tended to reduce $\mathrm{Fe}$ and $\mathrm{Mn}$ solubility, increasing the insoluble forms of these micronutrients in the soil (Barman et al., 2014).

\section{Acknowledgements}

This study was financed by the Junta de Andalucía, Spain, through Excellence Project P07-RNM-2746. M. Quirantes thanks the Junta de Andalucía, for its doctoral grant associated to project P07-RNM-2746. We thank the biomass power plants of Tradema, La Loma and Albaida for providing the different biomass ashes used in this study. The authors thank David Nesbitt for assisting in the translation of the manuscript into English.

\section{References}

Barman, M., Shukla, L.M., Datta, S.P., Rattan, R.K. 2014. Effect of applied lime and boron on the availability of nutrients in an acid soil. J. Plant Nutr. 37, 357-373.

Bougnom, B.P., Knapp, B.A., Etoa, F.X., Insam, H. 2011. Possible use of wood ash and compost for improving acid tropical soils. p. 87-106. In: H. Insam, and B.A. Knapp, (ed.). Recycling of biomass ashes.Springer, Heidelberg, Germany.
Demeyer, A., Voundi, J.C., Verloo, M.G. 2001 Characteristics of wood ash and influence on soil properties and nutrient uptake, an overview. Bioresour. Technol. 77, 287-295.

Hosseinpur, A.R., Motaghian, H. 2015. Evaluating of many chemical extractants for assessment of $\mathrm{Zn}$ and $\mathrm{Pb}$ uptake by bean in polluted soils. J. Soil Sci. Plant Nutr. 15, 24-34.

Huotari, N., Tillman-Sutela, E., Moilanen, R. 2015. Recycling of ash - For the good of the environment?. Forest Ecol. Manag. 348, 226-240.

Knapp, B.A., Insam, H. 2011. Recycling of biomass ashes: current technologies and future research needs. p. 1-16. In: H. Insam, and B.A. Knapp, (ed.). Recycling of biomass ashes. Springer, Heidelberg, Germany.

Krook, J., Mårtensson, A., Eklund, M. 2006. Sources of heavy metal contamination in Swedish wood waste used for combustion. Waste Manage. 26, 158-166.

MAPA, 1986. Official methods of analysis. Volume III. Plants, organic products, fertilizers, soils, waters and organic fertilizers. Secretaría General Técnica del Ministerio de Agricultura, Pesca y Alimentación, Madrid.

Molina, M., Ortega, R., Escudey, M. 2012. Evaluation of the AB-DTPA multiextractant in Chilean soils of different origin with special regard to available phosphorus, Arch. Agron. Soil Sci. 58, 789-803.

Omil, B., Sánchez-Rodríguez, F., Merino, A. 2011 Effects of ash applications on soil status, nutrition, and growth of Pinus radiata D. Don Plantations. p. 69-86. In: H. Insam, and B.A. Knapp, (ed.). Recycling of biomass ashes. Springer, Heidelberg, Germany. 
Sirikare, N.S., Marwa, E.M., Semu, E., Naramabuye, F.X. 2015. Liming and sulfur amendments improve growth and yields of maize in Rubona Ultisol and Nyamifumba Oxisol. Acta Agr. Scand. B-S P 65, 713-722.

Soltanpour, P.N. 1985. Use of ammonium bicarbonate DTPA soil test to evaluate elemental availability and toxicity. Commun. Soil Sci. Plan. 16, 323338.
Soltanpour, P.N., Schwab, A.P. 1977. A new soil test for simultaneous extraction of macro and micronutrients in alkaline soils.Commun. Soil Sci. Plan. 8, 195-207. 